\title{
THE MEANING EXTENSION OF OVER: A CRITIQUE OF KEY THEORIES
}

\author{
Do Tuan Long*, Vu Thi Huyen Trang \\ VNU University of Languages and International Studies, \\ Pham Van Dong, Cau Giay, Hanoi, Vietnam \\ Received 4 April 2019 \\ Revised 8 January 2020; Accepted 14 February 2020
}

\begin{abstract}
This paper summarizes different approaches to the meaning extension of the English preposition over and proposes a multimodal approach comprising three spatial image theories and one mental space theory in reference to an image-based view. It is concluded that the author's proposal is a combination of Deane's 2005 multimodal spatial representations and 2017 Kövecses's model, in which there is an emphasis that treating the spatial configurations of a spatial marker requires different frames and when the marker denotes a non-spatial sense, there exists an activation of a metaphor layered from its frame in certain context with a specific communicative purpose to the domain of which the frame is a part and finally the activation will reach the image schema that supports the frame.
\end{abstract}

Keywords: metaphor, over, meaning transference, mechanisms

\section{Introduction}

English prepositions are used before nouns to denote a spatial configuration between the Figure and the Ground (Talmy, 2000). However, they also indicate a "non-spatial" configuration as shown in the following two examples:

(1) Dangers are over the man's head.

(2) Year on year, the company is performing below par. (Tyler \& Evans, 2003)

In the first sentence, the virtual ground is the man's head while the figure is dangers, and readers could realize the concept of imminent dangers menacing the man as if they (dangers) were just above his head. The second sentence reveals the company's worse performance than the usual/expected standard (the par). There are two main proposals giving

* Corresponding author: Tel.: 84-985227867

Email: tuanlongcfl@gmail.com/longdt1990@vnu.edu.vn an explanation for such a usage. Firstly, Lakoff and Johnson (1980) accounted for the meaning transference ${ }^{1}$ in those sentences to be image-schema transformations, or in other words, metaphors are used to transfer non-spatial senses. Besides, Tyler and Evans (2003) analyzed the meaning transference in reference to the encyclopedic knowledge and metaphor, showing the perceptual resemblance and experiential correlation between the space and abstract domain are two mechanisms for sense extension.

However, the use of over in the following sentence is more complicated than it is in the previous ones:

(3) The British Ambassador in hot water over joke. (BBC headline)

\footnotetext{
1 Two terms "sense" and "meaning" have to be distinguished here. Sense refers to a particular meaning of a preposition in contexts of use while meaning is more general, referring to the whole senses of a preposition.
} 
A componential analysis of sentence (3) provides readers with a structure of a prepositional phrase (in hot water) + over + a noun phrase (joke). Do (2016) observed that if the prepositional phrase refers to an unpleasant feeling or experience, the noun phrase succeeding over could be the cause or reason. A further reading of the article offers the "caused by" use of over, which is explained by only Collins Dictionary ${ }^{2}$. Moreover, over in the previous sentence could not be represented in an image-schema as an image-schema must be specific enough to be visualized (Aitchison, 1987, pp. 42-43; Palmer, 1981, pp. 25-26; Johnson, 1980, 1999).

As being shown, the use of a preposition, e.g. over, is not always simple. Therefore, in this paper we would analyze different approaches to the sense extension of over, and then propose a potential framework to treat its role as both spatial and non-spatial markers, which might serve as a basis for the discussion of sense extension of other prepositions.

\section{A critique of different approaches to sense extension of over}

\subsection{Full-specification Approach}

Over is treated by Lakoff as a case study in English prepositions (Lakoff, 1987, pp. 416461) and his analysis is sometimes described as the full-specification approach to lexical semantics in later literature review (Evans, 2001; Tyler \& Evans, 2003; Deane, 2005). In the analysis, twenty-two senses of over were accounted, mostly prepositional usages, one verb-particle construction and one verbal prefix. The core point in the theory is that the senses associated with prepositions like over, which are grounded in spatial experience, are structured in terms of image-schemas. Lakoff supposes that an image schema combining elements of both ABOVE and ACROSS is the prototypical sense of over. The distinct senses associated with over are structured with respect to this image-schema which provides the category with its prototype structure. Furthermore, according to Lakoff, some of the connections among schemas can only be defined in imagistic terms.

Lakoff claims that the schemas which are different from the central schema are considered to represent distinct senses associated with over. According to this model of word meaning, the central schema for over has at least six distinct and closely related variants (see Figure 1), each of which is stored in semantic memory.

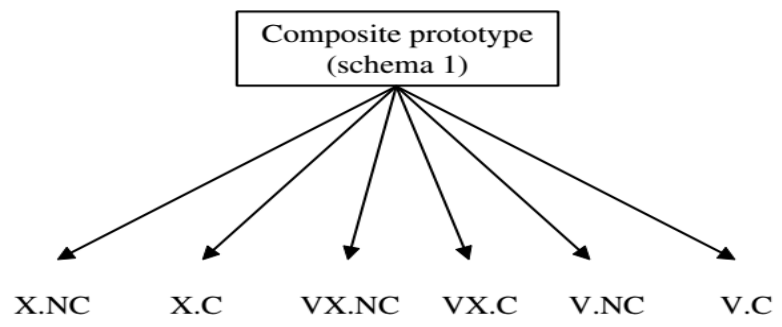

Figure 1. Central image schema (adopted from Lakoff, 1987, p.423)

Given the range of senses over is associated with in addition to the ABOVE-

2. https://www.collinsdictionary.com/dictionary/ english/over1
ACROSS sense (summarized in Table 1), this model results in a potentially vast proliferation of senses for each lexical item. 
Table 1. Schemas proposed by Lakoff (1987) for over besides the central schema

(Evans \& Green, 2006, p.337)

\begin{tabular}{|c|c|c|}
\hline Schema type & Basic meaning & Examples \\
\hline ABOVE schema & The TR is located above the LM. & $\begin{array}{l}\text { The helicopter is hovering over the } \\
\text { hill. }\end{array}$ \\
\hline COVERING schema & The TR is covering the LM & The board is over the hole. \\
\hline REFLEXIVE schema & $\begin{array}{l}\text { The TR is reflexive: the TR is } \\
\text { simultaneously the TR and the } \\
\text { LM. The final location of the TR is } \\
\text { understood with respect to its starting } \\
\text { position }\end{array}$ & The fence fell over. \\
\hline EXCESS schema & $\begin{array}{c}\text { When over is employed as a prefix it } \\
\text { can indicate 'excess' of TR relative to } \\
\text { LM }\end{array}$ & The bath overflowed. \\
\hline REPETITION schema & $\begin{array}{c}\text { Over is used as an adverb to indicate a } \\
\text { process that is repeated. }\end{array}$ & $\begin{array}{c}\text { After receiving a poor grade, the } \\
\text { student started the assignment over } \\
\text { (again). }\end{array}$ \\
\hline
\end{tabular}

Here are some more examples for the table 1:

Schema 1. The plane flew over.

Schema 1.X.NC. The plane flew over the yard.

Schema 1.VX.NC. The plane flew over the hill.

Schema 1.V.NC. The bird flew over the wall.

Schema 1.X.C. Sam drove over the bridge.

Schema 1.VX.C. Sam walked over the hill.

Schema 1.V.C. Sam climbed over the wall.

Schema 1.VX.C.E. Sam lives over the hill.

Schema 1.X.C.E. Sausalito is over the bridge.

Schema 2. Hang the painting over the fireplace.

Schema 2.1DTR. The power line stretches over the yard.

Schema 3. The board is over the hole.

Schema 3.P.E. The city clouded over.

Schema 3.MX. The guards were posted all over the hill.

Schema 3.MX.P. I walked all over the hill.

Schema 3.RO. There was a veil over her face.

Schema 3.P.E.RO. Ice spread all over the windshield.

Schema 3. MX.RO. There were flies all over the ceiling.

Schema 3. MX.P.RO. The spider had crawled all over the ceiling.

Schema 4. Roll the log over.

Schema 4.RFP. The fence fell over.

Schema 5. The bathtub overflowed.

Schema 6. Do it over.

The numbers from 1 to 6 are "above and across", pure "above", "covering", "curved trajectory", "excess", and "repetition" respectively. Each schema is labelled for its salient properties. Additional specifications vary along several dimensions: the landmark (LM, or reference object), may be horizontally $(\mathrm{X})$ or vertically $(\mathrm{V})$ extended. It may also be one dimensional (1DTR) or not. There may be contact $(\mathrm{C})$ or noncontact $(\mathrm{NC})$ between the LM and the TR. The TR may be multiplex (multiple entities or locations) or mass (a continuous medium). Various remaining distinctions are indicated: $\mathrm{P}$ indicates a connecting path, E indicates location at the end of a trajectory (end-point focus), and RO indicates a relation rotated from its normal orientation.

According to Lakoff, metaphors take image-schemas as their input; and hence, the 
emergence of the metaphorical use of over in the sentence, She has a strange power over $m e$, is explained:

...this is an instance of a very common metaphor: CONTROL IS UP; LACK OF CONTROL IS DOWN (Lakoff and Johnson,1980:15). Over in this sentence is an extension of schema 2, where the trajector is simply above the landmark (Lakoff, 1987:426).

\subsection{A critique of Full-specification Approach}

In our opinion, there are four problems with the full-specification approach: (i) the methodology is unconstrained; (ii) there is a lack of a rigorous theory of images; (iii) the context-bound interpretations of the lexical networks would clear risks of misanalysis; and (iv) there is a lack of systematic analysis of how certain metaphors emerge associated with over.

To begin with, Lakovian approach has been blamed for a lack of methodological constraints. In other words, Lakoff provides no principled criteria for determining what counts as a distinct sense. This means that the polysemy account presented for over (or whatever lexical item we might apply the approach to) results purely from the intuitions (and perhaps also the imagination) of the analyst rather than actually representing the way a particular category is represented in the mind of the language users.

Secondly, though Lakoff's analysis is based on image-schema, he fails to set a rigorous theory of images. This makes the semantic description of over become "an informal exercise" without predictive power (Deane, 2005, p.6).

Thirdly, Lakoff used linguistic context of an utterance containing over to analyze its meaning, or context-bound interpretations in other words, leading to a clear risk of misanalysis. One example is the following sentences:

\section{(4) a. The bird flew over the wall.}

b. Sam climbed over the wall.

Following Lakoff, over in sentences (4a) and (4b) has two distinct senses in reference to contact or without contact. However, the interpretation of over with respect to contact or lack of contact derives from the integration of over with the other elements in the sentence. Human knowledge about birds (they can fly) and people (they cannot), provides readers with the inference that birds do not come into contact with walls when crossing over them while people do. In other words, the linguistic context together with encyclopedic knowledge provides the details relating to the presence or absence of contact. Therefore, over here is vague with respect to contact (Tyler and Evans, 2003).

Last but not least, the sense extension of over as a preposition is arbitrarily presented because there is no systematic analysis of the mappings from the source to the target domains.

\subsection{Reformulating the challenge of 'over'}

This is the challenge of over: to formulate a framework describing the process by which abstract senses are extended. We will consider the following analyses: (i) Boers, 1996; (ii) Tyler \& Evans, 2003; and (iii) Deane, 2005.

\subsubsection{Image-schema transformations} approach

Boers (1996) made use of the Conceptual Metaphor Theory (CMT), the standard version in later literature, by Lakoff and Johnson (1980) to treat the sense extensions of over (Kövecses, 2006), and the notion of image-schemas serve as a basis for further discussion. In general, Boers' analysis is in line with the previous description of Lakoff (1987). The following table summarizes Boers' analyses: 
Table 2. A summary of Boer's analysis of over

\begin{tabular}{|c|c|c|}
\hline Senses & In physical space & In other domains \\
\hline $\begin{array}{c}\text { 1. Above and } \\
\text { across }\end{array}$ & $\begin{array}{l}\text { The TR is not in contact and } \\
\text { higher than the LM. The shape of } \\
\text { the TR and LM varies depending } \\
\text { on contexts. }\end{array}$ & $\begin{array}{l}\text { 1. The CONDUIT metaphor } \\
\text { E.g.: We talk about it over breakfast. } \\
\text { 2. Linguistic (inter)action is a path } \\
\text { E.g.: Talking over his problems. } \\
\text { 3. Cognitive action is a path } \\
\text { E.g.: Thinking over the results of the meeting. } \\
\text { 4. An activity is a path } \\
\text { E.g.: Plenty of food is left over. } \\
\text { 5. Life is a journey. } \\
\text { E.g.: "to get over this difficulty we should ..." } \\
\text { 6. Proximity is (near) identity and distance is difference } \\
\text { E.g.: New York swung over from opposition to } \\
\text { ratification or the new laws. } \\
\text { 7. A transaction is a path } \\
\text { E.g.: He handed over the briefcase to the mugger. } \\
\text { 8. Time is a path and we move on it } \\
\text { E.g.: We have seen considerable changes over the years. } \\
\text { 9. Time is a moving object } \\
\text { E.g.: Those days are now over. }\end{array}$ \\
\hline 2. Above & The TR is higher than the LM & $\begin{array}{l}\text { 1. Cognition is perception } \\
\text { E.g.: He had little hope over her recovery. } \\
\text { 2. More is up, less is down } \\
\text { E.g.: They produced over } 70000 \text { tons of iron a year. } \\
\text { 3. High status is up + Having control or force is up } \\
\text { E.g.: He holds the reins of power over the party. } \\
\text { In this metaphor, the metonymic basis of these } \\
\text { metaphors (bodily posture, etc.) may still be felt in, for } \\
\text { example: a tower suggesting domination over the other } \\
\text { buildings }\end{array}$ \\
\hline 3. Covering & $\begin{array}{l}\text { The sense is related to the } \\
\text { Above sense, but the TR is } \\
\text { conceptualized as a surface with } \\
\text { or without contact with the LM. }\end{array}$ & $\begin{array}{l}\text { 1. Truth is a hidden object }+ \text { Cognition is perception. } \\
\text { E.g.: His reputation as an artist drew a glittering curtain } \\
\text { over his other characteristics. } \\
\text { 2. Having force or control is up; being subjected to } \\
\text { force or control is down } \\
\text { E.g.: A wave of nostalgia swept over me... }\end{array}$ \\
\hline $\begin{array}{l}\text { 4. Reflexive } \\
\text { sense }\end{array}$ & $\begin{array}{l}\text { In reflexive schemas the } \mathrm{TR} \text { and } \\
\text { the } \mathrm{LM} \text { are one and the same } \\
\text { entity }(\mathrm{TR}=\mathrm{LM}) \text {. }\end{array}$ & $\begin{array}{l}\text { Mentally rotating an entity can also be described by } \\
\text { means of reflexive over. } \\
\text { E.g.: I turned the question over in my head. }\end{array}$ \\
\hline
\end{tabular}

We suppose that there are two problems with this approach: (i) the issue of methodology and (ii) the issue of the direction of analysis. In the first place, the methodology of CMT focuses on the basis of intuitive and unsystematically found linguistic metaphor
(Pragglejaz, 2007). Recall the information provided in Table 2, we could realize that the metaphor of "Having force or control is up; being subjected to force or control is down" is derived from both Covering sense and Above sense of over. What is the difference between 
the two kinds of metaphor derived from the two aforementioned senses? What are the salient remaining aspects of the source domain in the target domain through the mappings? How could the conceptual metaphors emerge? Those questions do not seem to have any answers yet. Additionally, the second issue concerns the direction of analysis, whether it is top-down or bottom-up (Dobrovolskij \& Piirainen, 2005; Stefanowitch, 2007).
Though Boers analyzed instances of use of over in a corpus, he still followed the topdown direction instead of showing that a given conceptual metaphor of over is a result of a multi-stage procedure (Steen, 1999). All in all, the following model advocated by Kövecses (2017) is compatible with analyzing the emergence of certain metaphors associated with over from bottom-up direction:

\section{IMAGE SCHEMAS}

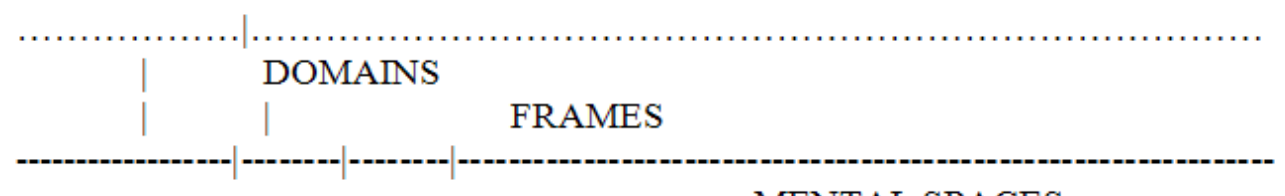

MENTAL SPACES

Figure 2. Activation from MENTAL SPACES to FRAMES, DOMAINS, and IMAGE SCHEMAS (after Kövecses, 2017)

The link is a continuum from mental spaces to frames, domains and finally the image-schemas. A metaphor that is used in a specific communicative situation as part of a mental space, or scene, will activate the frame structure to which it is linked, which will, in turn, activate the domain of which the frame is a part, and the activation will reach the image schema that conceptually supports the frame. This proposal is consonant with a number of others in the cognitive linguistic study of metaphor, such as Lakoff's (1991) "invariance principle" and Ruiz de Mendoza's (1998) "extended invariance principle."

\subsubsection{Principled Polysemy}

The framework Principled Polysemy first introduced in the book "The Semantics of English Prepositions" in 2003 is used to analyze the meanings of certain English prepositions and present them in semantic networks. Over was taken as a case study to shed light on the analysis of other prepositions. The two authors provided a semantic network for over with one central meaning and fifteen extended meanings (see Figure 3).

Tyler and Evans (2003) followed Lakovian idea that a preposition (or a word) has prototypical meaning and then from this meaning other extensions occur. So, it is necessary first to identify the prototypical meaning of a preposition and present other meaning extensions in a semantic network for that preposition. According to them, the prototypical meaning of a word needs to have four following characteristics: (1) earliest attested meaning; (2) predominance in the semantic network; (3) relations to other prepositions; and (4) ease of predicting sense extensions. After finding the prototypical meaning of a preposition, it is crucial to decide whether a particular sense of a preposition counts as a distinct sense and can, therefore, be established as a case of polysemy. Founders of the framework provided two criteria: (i) for a sense to count as distinct, it must involve a meaning that is not purely spatial in nature, and/or a spatial configuration holding between the TR and LM that is distinct from the other senses conventionally associated with that preposition; and (ii) there must also be instances of the sense that are contextindependent: instances in which the distinct sense could not be inferred from another sense and the context in which it occurs. 
The two authors when explaining the mechanisms of meaning extension relied on context-bounds and tried to provide their explanation in reference to perceptual resemblance, experiential correlation, online meaning construction and pragmatic strengthening.

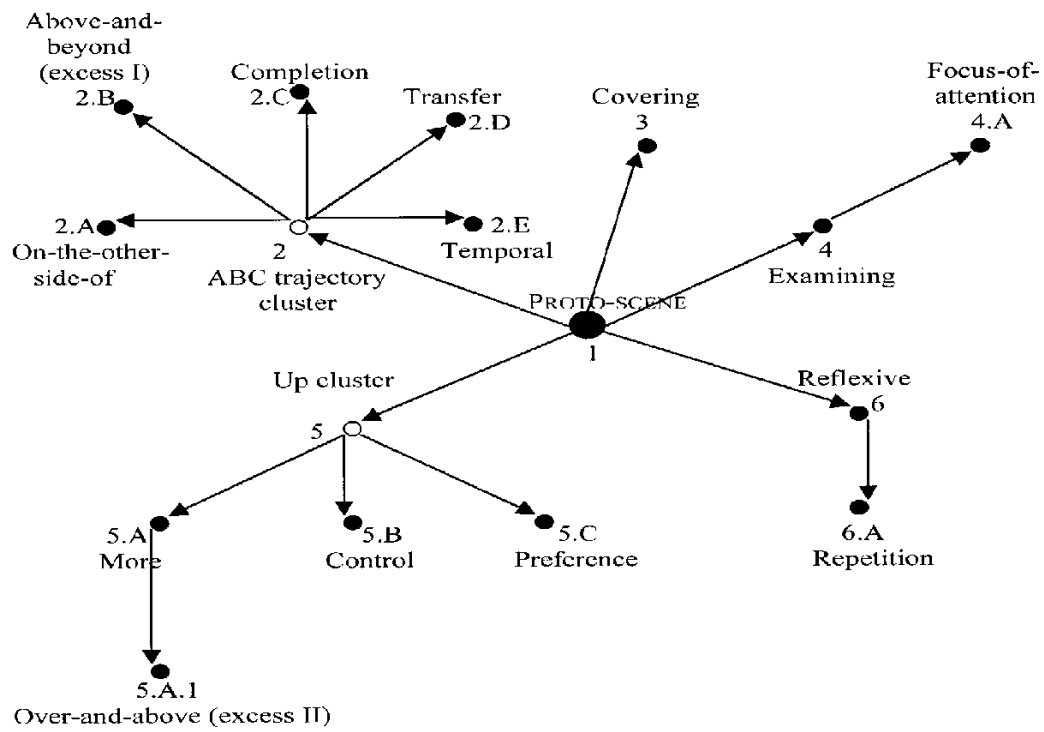

Figure 3. The semantic network for over (Tyler \& Evans, 2003, p.80)

The review of both spatial and non-spatial senses of over is shown in the following table:

Table 3. The total senses of over in its semantic network (Do, 2016)

\begin{tabular}{|c|c|c|}
\hline Senses & Graphic Illustrations & Examples $^{1}$ \\
\hline 1. Proto-scene & $\bullet$ & (5) The picture is over the mantle. \\
\hline $\begin{array}{l}\text { 2A. On-the- } \\
\text { other-side-of }\end{array}$ & & $\begin{array}{l}\text { (6) Arlington is over the Potomac River from } \\
\text { Georgetown. }\end{array}$ \\
\hline $\begin{array}{l}\text { 2B. Above and } \\
\text { Beyond (Excess } \\
\text { I) }\end{array}$ & & $\begin{array}{l}\text { (7) The arrow flew over the target and landed } \\
\text { in the woods. }\end{array}$ \\
\hline 2C. Completion & START & $\begin{array}{l}\text { (8) Most of what he was saying went over her } \\
\text { head, as did any conversation that was not } \\
\text { personal. }\end{array}$ \\
\hline 2D. Transfer & (1) & $\begin{array}{l}\text { (9) Sally turned the keys to the office over to } \\
\text { the janitor. }\end{array}$ \\
\hline 2E. Temporal & $\rightarrow$ & $\begin{array}{l}\text { (10) Over the waffles next morning, Pittypat } \\
\text { was lachrymose, Melanie was silent and } \\
\text { Scarlett defiant. }\end{array}$ \\
\hline
\end{tabular}

Some examples are extracted from "Gone with the Wind" and "Vanity Fair", the others are Tyler \& Evans'. 


\begin{tabular}{|c|c|c|}
\hline 3. Covering & & $\begin{array}{l}\text { (11) Of course, her brooch could be pinned } \\
\text { over the spot, but perhaps Melanie had sharp } \\
\text { eyes. }\end{array}$ \\
\hline 4. Examining & & $\begin{array}{l}\text { (12) Once, in looking over some drawings } \\
\text { which Amelia had sent from school, Rebecca } \\
\text { suddenly came upon one which caused her to } \\
\text { burst into tears and leave the room. }\end{array}$ \\
\hline $\begin{array}{l}\text { 4A. Focus-of- } \\
\text { attention }\end{array}$ & $<(\bullet)>$ & $\begin{array}{l}\text { (13) It was pushed out now, and Scarlett knew } \\
\text { that Mammy was seething over something of } \\
\text { which she did not approve. }\end{array}$ \\
\hline 5A. More & & $\begin{array}{l}\text { (14) Three were killed and over } 260 \text { injured } \\
\text { when two bombs detonated. }\end{array}$ \\
\hline $\begin{array}{l}\text { 5A1. Over-and- } \\
\text { Above } \\
\text { (Excess II) }\end{array}$ & & $\begin{array}{l}\text { (15) The heavy rains caused the river to flow } \\
\text { over its banks. }\end{array}$ \\
\hline 5B. Control & & (16) She has a strange power over me. \\
\hline 5C. Preference & & (17) I would prefer tea over coffee. \\
\hline 6. Reflexive & & $\begin{array}{l}\text { (18) } \\
\text { i. The fence fell over. } \\
\text { ii. He turned the page over. } \\
\text { iii. The tree bent over in the wind. }\end{array}$ \\
\hline 6A. Repetition & & (19) He played the same piano piece over. \\
\hline
\end{tabular}


From the table, it could be seen that the generic schemas of over is 6, similarly to what was presented by Lakoff (1987) though there are some differences. In reference to our objective in this paper, we will first present and then comment on how each non-spatial sense of over is derived from the spatial sense in the light of Principled Polysemy.

The first group of senses is the $\mathrm{ABC}$ trajectory cluster, consisting of three nonspatial senses: Completion, Transfer and Temporal. According to Tyler and Evans
(2003), the three extended senses are closely related to the spatial configuration denoted in the following sentence:

(20) The boy walked over the hill. (Tyler \& Evans, 2003)

The TR is the boy while the LM is the hill which will eventually obscure the vision of the viewers/ construers. The ABC trajectory is shown in the figure follow: the arrow is the path of walking; the emoji face represents the agent (boy):

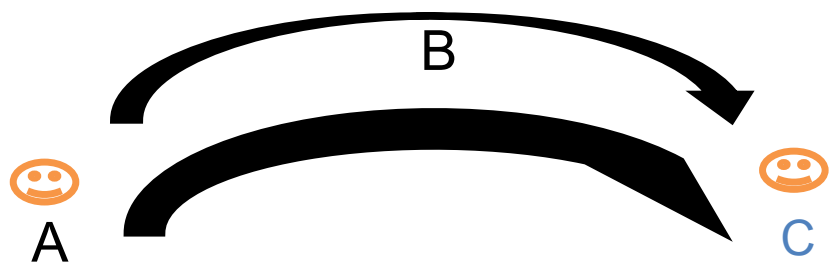

Figure 4. Schematization of "over the hill"

Three points $\mathrm{A}, \mathrm{B}$, and $\mathrm{C}$ are the most significant ones in the process of walking because they are salient slices in the process. The boy started at A, moved to B (the middle point) and finished at $\mathrm{C}$. When the whole process completes, the utterance "over the hill" is reasonable. Cognitively, the Completion Sense conjures up a virtual process from A to $\mathrm{C}$; the Transfer Sense requires the emergence of $\mathrm{A}$ and $\mathrm{C}$ while $\mathrm{B}$ could perhaps be replaced by the preposition to; the Temporal Sense is conceptualized as a straight path from A to C.

Both the Examining Sense and Focus-ofAttention Sense are conceptualized as "above and proximal" in Tyler and Evans' term. Two senses might arise from the construal of such the following sentence in which the TR and LM are schematized in figure 5:

(21) Phillip is standing over the entrance to the underground chamber. (Tyler \& Evans, 2003, p.93)

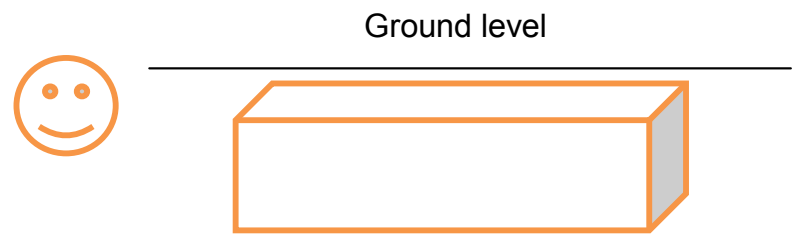

Figure 5. Schematizing the spatial configuration in Example (21)

Tyler \& Evans (2003) propose that the TR is higher but proximal to the LM and in this case the TR can closely look at or observe the LM; therefore, the day-by-day experience with many recurring examples give rise to the
Examining Sense and the Focus-of-Attention Sense.

According to Tyler and Evans (2003), the Repetition Sense emerges because of three possibilities of the sense emergence: (i) the 
iterative effect of the Reflexive Sense; (ii) the iterative application of the $\mathrm{ABC}$ trajectory; and (iii) the conceptual blend of both the notions of completion and reflexivity.

From the above presentation, we could realize that Tyler and Evans' analysis is based on inference of context-bound, which may result in the vast proliferation of hypotheses. In other words, the problem of sense contiguity comes into play (Deane, 2005). In order to illustrate our view, we will show how On-theother-side-of Sense could emerge. Tyler and Evans (2003) suppose that the sense is a result of the reanalysis of the $\mathrm{ABC}$ trajectory cluster; however, we propose that it can be derived directly from the prototypical sense from a different vantage.

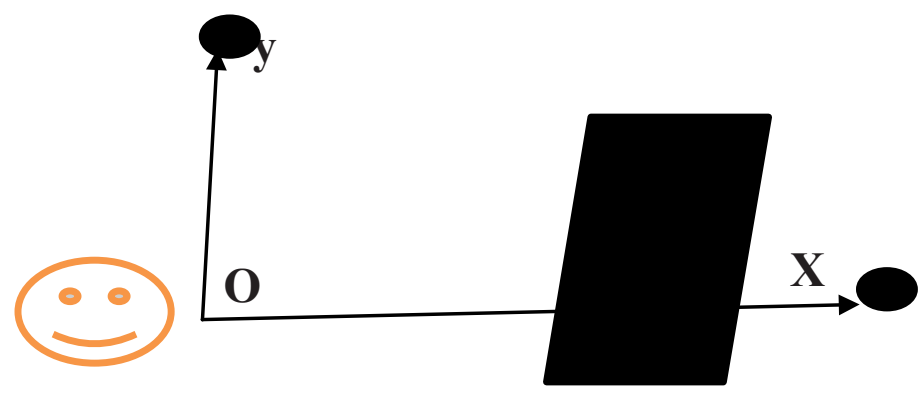

Figure 6. Egocentric view of On-the-other-side-of Sense of over

Provided that $x$ refers to Arlington (a place) while $y$ could be any place above the interlocutor; and in this case, three points Oxy constitute a space/ flat, as shown in Figure 6. If we put up the axis Ox, we would have the following figure:

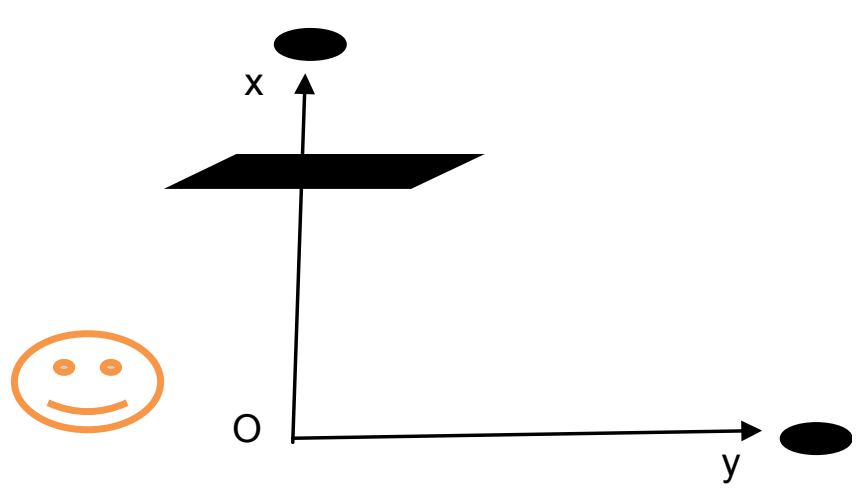

Figure 7. A converse version of Figure 6

It is seen that the spatial scene involving the Ox axis is partially similar to the spatial configuration of the Covering Sense of under. However, Arlington $(x)$ is now above the river, and anyone to $x$ must go across the river. Therefore, it is reasonable to conclude that On-the-other-side-of Sense could directly derive from the prototypical sense. We should also bear in mind that if the speaker and Arlington are not on the same river bank, i.e. they are on different sides of the river, the use of over must be changed into "next to" or "by" to locate the relative position of Arlington and the river from the location of the speaker.

The second issue with Principled Polysemy is that the semantic network for over by Tyler and Evans is too simple, admitted by Evans (2014): ...it is probably overly simplistic to assume, as has sometimes been done (e.g., Tyler \& Evans, 2001, 2003) that 
discussions of polysemy boil down to the polemic of monosemy on the one hand, versus the multiple distinct sense-units of the principled polysemy approach that I espoused with Andrea Tyler in our 2003 book. This bifurcation is too neat... (Evans, 2014)

What is more, instances of use of over in such cases as sentence (3) remain unanswerable in the light of Principled Polysemy. We could not account for such cases as online construction meaning as if over is used online, it should be used once only (Croft \& Cruise, 2004).

Lastly, Tyler and Evans ignore the role of mental spaces or scenarios/ scenes which are fully specific as suggested by Musolff. The elements of mental spaces are values not roles, adding new elements from the same frame, they make new inferences and evaluations possible in context; they blend source and target frames, and so on (Kövecses, 2015).

In general, the inference-based approach of Principled Polysemy seems to fail to explain how non-spatial senses of over emerge; and the links between each sense are arbitrarily presented.

\subsection{Multimodal Image Theory}

Deane (2005), exploiting a multiple reference frame to treat over from three perspectives, shows that the seemingly distinct senses are in fact one sense being looked at from a different perspective. Three frames of Deane's multimodal spatial representations are: the visual space (spatial relations as image-complexes); the kinetic space (in reference to action and force dynamics); and the maneuver space (in reference to Orientation and Alignment). Particularly, Deane's model of Multimodal Image Theory is backed up by three principles in three aforementioned frames:

(i) Preference rule principle: A variant construal may be formed by combining a subset of images from the prototype.

(ii) Stereoscopic Principle: Representations employing object-centered fields are stereoscopic images, and must therefore consist of at least two images which represent the same scene but differ in the coordinates or resolution from which they view the scene.

(iii) Distinctiveness Principle: If an image or an image-complex is part of the prototype for a preposition, it cannot be used as a semantic variant of another preposition.

It is seen that the number of distinct senses associated with English prepositions is reducing systematically. Details of the senses denoted by over are discussed by Deane (ibid: 42-90). In fact, the model advocated by Deane has successfully bridged the gaps that previous approaches left. Firstly, it presents the sense development of over as a system from the prototypical sense to extended ones through three aforementioned principles, showing that the interpretation of over is a multi-stage cognitive process. Distinct sense, e.g. On-the-other-side-of or Covering sense presented by Tyler and Evans, are variants of the prototypical sense. Secondly, the framework has rigorous constraints on what counts as distinct sense, solving the issue of sense redundancy. However, the non-spatial senses of over are not treated in the light of Multimodal Space Image Theory. Therefore, in order to explain how non-spatial senses of over develop from spatial ones, there is a need of a combination between space and nonspace frames of analysis.

\section{Conclusion}

In conclusion, regarding the goal of the paper, we have reviewed four notable works to treat over by different scholars (Lakoff, 1987; Boers, 1996; Tyler \& Evans, 2003; Deane, 2005). The Full-specification approach advocated by Lakoff is criticized for failing to set a theoretical constraint and no advance was shown in comparison with purely descriptive account. The Principled Polysemy framework introduced by Tyler and Evans (2003) provides rigid constraints to determine 
the prototypical sense of spatial prepositions, and to count a sense as distinct. However, this framework is also claimed to be too simple, as admitted by Evans (2014). Boers' (1996) top-down analysis of conceptual metaphors associated with over seems to be arbitrary and could not show spatial cognition is a multistage process. Last but not least, the model of Multimodal Spatial Representations by Deane (2005) proves to be successful, solving the remaining issues that other accounts left. It is suggested that the image-schema based view of over is an appropriate approach including four spaces: the visual space (spatial relations as image-complexes); the kinetic space (in reference to action and force dynamics); the maneuver space (in reference to Orientation and Alignment); and the mental space (in reference to virtual relations between figure and ground, in which CMT is the analysis tool). In other words, we advocate a combination between Multimodal Spatial Representations (Deane, 2005) and Mental Space from bottom-up direction (Kövecses, 2017) to treat the issue raised in the paper.

\section{References}

Aitchison, J. (1987). Words in the Mind: An Introduction to the Mental Lexicon. Oxford/ New York: Basil Blackwell.

Barcelona, A. (2003). Metaphor and metonymy at the Crossroads: A cognitive perspective. Berlin: Mouton De Gruyter.

Brugman, C. (1981). The story of OVER. Unpublished MA thesis, University of California: Berkeley.

Boers, F. (1996). Spatial Prepositions and Metaphor: A Cognitive-semantic Journey along the UP-DOWN and the FRONT-BACK Dimensions. Tübingen: Gunter Narr.

Brenda, M. (2014). The Cognitive Perspective on the Polysemy of the English Spatial Preposition over. Cambridge: Cambridge Scholars Publishing.

Coventry, K. R., Richard, C. \& Simon, C. G. (1994). Spatial prepositions: object specific function and task requirements. Journal of Semantics, 11(4), 289-309.

Croft, W. \& Cruise, A. D. (2004). Cognitive Linguistics. Cambridge: Cambridge University Press.

Deane, P. D. (2005). Multimodal spatial representation: on the semantic unity of over. In From Perception to Meaning: Image Schemas in Cognitive Linguistics,
Beate, H. \& Grady, J. (eds), 235-284. Berlin/New York: Mouton de Gruyter.

Dewell, R. B. (1994). Over again: Image-schema transformations in semantic analysis. Cognitive Linguistics, 5(4), 351-380.

Dobrovolskij, D., \& Piirainen, E. (2005). Figurative Language: Cross-cultural and Cross-linguistic Perspective. Amsterdam: Elsevier.

Evans, V. (2004). The Structure of Time: Language, Meaning and Temporal Cognition. Amsterdam: John Benjamins.

Evans, V. (2005). The meaning of time: polysemy, the lexicon and conceptual structure. J. Linguist, 41(1), 33-75.

Evans, V. (2006). Lexical concepts, cognitive models and meaning-construction. Cognitive Linguist, 17(4), 491-534.

Evans, V. (2009). How Words Mean: Lexical Concepts, Cognitive Models and Meaning Construction. Oxford: Oxford University Press.

Evans, V. (2010a). From the spatial to the non-spatial: the 'state' lexical concepts of in, on and at. In: Evans, V., Chilton, P. (Eds.), Language, Cognition \& Space, 215-248. London: Equinox.

Evans, V. (2010b). Figurative language understanding in LCCM Theory. Cognitive Linguist, 21(4), 601-662.

Evans, V. (2013). Language and Time: A Cognitive Linguistics Approach. Cambridge: Cambridge University Press.

Evans, V. (2014). A unified account of polysemy within LCCM Theory. Lingua, 157, 100-123.

Evans, V. (2015). What's in a concept? Analog versus parametric concepts in LCCM Theory. In: Margolis, E., Laurence, S. (Eds.), The Conceptual Mind: New Directions in the Study of Concepts. Cambridge, MA: MIT Press.

Evans, V., \& Green, M (2006). Cognitive Linguistics: An Introduction. Edinburgh: Edinburgh University Press.

Evans, V., \& Tyler, A. (2004). Rethinking English prepositions of movement: the case of to and through. Belg. J. Linguist, Vol 18, 247-270.

Fauconnier, G. (1985). Mental Spaces. Cambridge: Cambridge University Press.

Fauconnier, G., \& Turner, M. (1998). Conceptual integration networks. Cognitive Science, 22(2), 31-187.

Fauconnier, G., \& Turner, M. (2002). The way we think: Conceptual Blending and the Mind's Hidden Complexities. New York: Basic Books.

Fillmore, C. (1982). Frame semantics. In Linguistics in the Morning Calm, ed. by The Linguistic Society of Korea, 111-137. Soeul: Hanshin.

Grady, J. (1997). Foundations of Meaning: Primary Metaphors and Primary Scenes. Unpublished Ph.D Dissertation. Berkeley: University of California Berkeley. 
Grady, J. (1999). A typology of motivation for conceptual metaphor: correlation vs. resemblance. In G.W. Gibbs \& G. Steen (eds), Metaphor in Cognitive Linguistics, 79-100. Amsterdam: John Benjamins.

Jackendoff, R. (1983). Semantics and Cognition. Cambridge, Massachusetts: MIT Press.

Johnson, M. (1987). The body in the mind: The bodily basis of meaning, imagination, and reason. Chicago, IL: University of Chicago Press.

Kövecses, Z. (1990). Emotion Concepts. Berlin and New York: Springer-Verlag.

Kövecses, Z. (1995). American friendship and the scope of metaphor. Cognitive Linguistics, 6, 315-346.

Kövecses, Z. (2000a). The scope of metaphor, in A. Barcelona (ed.) Metaphor and Metonymy at the Crossroads, 79-92. Berlin: Mouton.

Kövecses, Z. (2000b). Metaphor and Emotion. Cambridge and New York: Cambridge University Press.

Kövecses, Z. (2002). Metaphor. A Practical Introduction. Oxford and New York: Oxford University Press.

Kövecses, Z. (2005). Metaphor in Culture: Universality and Variation. Cambridge and New York: Cambridge University Press.

Kövecses, Z. (2010a). Metaphor. A Practical Introduction (2nd ed). Oxford and New York: Oxford University Press.

Kövecses, Z. (2010b). A new look at metaphorical creativity in cognitive linguistics, Cognitive Linguistics, 21(4), 663-697.

Kövecses, Z. (2015). Where Metaphors Come From: Reconsidering Context in Metaphor. Oxford and New York: Oxford University Press.

Kövecses, Z. (2017). Levels of metaphor. Cognitive linguistics, 28(2), 321-347.

Kreitzer, A. (1997). Multiple levels of schematicization: a study in the conceptualization of space. Cognitive Linguistics, 8(4), 291-325.

Lakoff, G. (1987). Women, Fire and Dangerous Tings: What Categories Tell Us about the Life of the Mind. Chicago/London: University of Chicago Press.

Lakoff, G. (1991). The invariance hypothesis. Is abstract reason based on image schemas? Cognitive Linguistics, 1, 39-74.

Lakoff, G. \& Johnson, M. (1980). The Metaphors We Live By. Chicago and London: University of Chicago Press.

Langacker, R. W. (1987). Foundations of cognitive grammar: Vol. 1. Theoretical prerequisites. Stanford: Stanford University Press.

Langacker, R. W. (2002). Concept, image, and symbol: The cognitive basis of grammar. (Originally published in 1991). Berlin and New York: Mouton de Gruyter. Lindstromberg, S. (2009). English prepositions explained. Amsterdam: John Benjamins.

Linder, S. (1981). A Lexico-semantic Analysis of English Verb Particle Constructions with "out" and "up”. Unpublished Ph.D Dissertation, University of California, San Diego.
Do, T. L. (2016). The meanings of English prepositions over, above, under, below and their potential equivalents in Vietnamese. Unpublished M.A Thesis, University of Languages and International Studies, Vietnam National University, Hanoi.

Do, T. L. (2018a). Over again: Potential novel perspectives from Lexical concepts and Cognitive models. VNU Journal of Foreign Studies, 34(4), 83103.

Do, T. L. (2018b). Over again: Novel perspectives from Lexical concepts and Cognitive models. In 2018 International Graduate Research Symposium Proceedings, Linguistics, Foreign Language Education Interdisciplinary Fields. Hanoi: Vietnam National University Press, Hanoi.

Musolff, A. (2006). Metaphor scenarios in public discourse. Metaphor and Symbol, 21(1), 23-38.

Pragglejaz Group. (2007). MIP: A method for identifying metaphorically used words in discourse. Metaphor \& Symbol, 22(1), 1-39.

Recanati, F. (2004). Literal Language. Cambridge: Cambridge University Press.

Roussel, E. (2013). Limit, Space and the Preposition Over. Cercles, 29, 198-225.

Ruiz de Mendoza, F. (1998). On the nature of blending as a cognitive phenomenon. Journal of Pragmatics, 30, 259-274.

Sandra, D., \& Rice, S. (1995). Network analyses of prepositional meaning: Mirroring whose mind the linguist's or the language user's? Cognitive Linguistics. 6(1), 89-130.

So, Y. Y. (2004). The polysemy network of over. SNU Working papers in English Language and Linguistics, 3, 63-78

Stefanowitch, A. (2007). Words and their metaphors. A corpus-based approach. In Stefanowitch, A. \& Gries, S.T. (Eds.,) Corpus-based Approaches to Metaphor and Metonymy, pp. 63 - 105. Berlin: Mouton de Gruyter.

Steen, G.et al. (2007). MIP: A method for identifying metaphorically used words in discourse. Metaphor and Symbol, 22(1), 1-39.

Sullivan, K. (2013). Frames and constructions in metaphoric language. Amsterdam: John Benjamins.

Sweetser, E. (1990). From etymology to pragmatics. New York: Cambridge University Press.

Talmy, L. (1983). How language structures space. In Pick, H. \& L. Acredolo (eds). Spatial Orientation Theory, Research and Application, 225-281. New York: Plenum Press.

Talmy, L. (2000). Toward a cognitive semantics, vol. II, Typology and process in concept structuring. Cambridge, MA: The MIT Press.

Taylor, J.R. (1989, 2003). Linguistic Categorization, Prototypes in Linguistic Theory. Oxford: Oxford University Press. 
Thora, T. (2004). Review of The Semantics of English Prepositions [Retrieved from http://linguistlist.org/ pubs/reviews/get-review.cfm?SubID $=18309$ on 20 June 2015]

Tyler, A., \& Evans, V. (2000). My first husband was Italian: Examining "exceptional" uses of English tense. Linguistic Agency of University of Duisburg (L.A.U.D) Series A: General and Theoretical Papers.

Tyler, A., \& Evans, V. (2001a). Reconsidering prepositional polysemy networks: the case of over. Language, 77(4), 724-765.

Tyler, A., \& Evans, V. (2001b). The Spatialization of Tense: A Cognitive Investigation of Exceptional Uses of English Tense. In M. Putz, S. Niemeier, \& R. Dirven (Eds.), Cognitive linguistic approaches to language pedagogy, 63-105. Berlin: Mouton de Gruyter.

Tyler, A., \& Evans, V. (2003). The semantics of English prepositions: Spatial scenes, embodied meaning, and cognition. Cambridge: Cambridge University Press.

Tyler, A., \& Evans, V. (2004). Applying cognitive linguistics to pedagogical grammar: the case of over. In M. Achard, \& S. Niemeier (Eds.), Cognitive linguistics, second language acquisition, and foreign language teaching, 257-280. Berlin: Mouton de Gruyter.

Tyler, A. et al. (2011). Applying Cognitive Linguistics to Learning the Semantics of English to, for and at: An Experimental Investigation. VIAL, 8, 122-139.

\title{
SỤ’ MỞ RỘNG NGHĨA CỦA GIỚI TƯ’ TIẾNG ANH “OVER": NHÌN LẠI NHŨ̃NG HƯỚNG NGHIÊN CỨU CHÍNH
}

\author{
Đỗ Tuấn Long, Vũ Thị Huyền Trang
}

\section{Truoòng Đại học Ngoại ngũu, Đại học Quốc gia Hà Nội, Phạm Văn Đồng, Cầu Giấy, Hà Nội, Việt Nam}

Tóm tắt: Bài viết này tóm lược và đưa ra nhận định về một vài đường hướng phân tích hiện tượng mở rộng nghĩa của giới từ over và đưa ra đề xuất về Mô hình Đa phương thức kết hợp giữa ba thuyết hình ảnh không gian và một thuyết hình ảnh không gian tinh thần dựa trên hình ảnh (image-based view). Đề xuất của chúng tôi về cơ bản hoàn toàn trùng khớp với mô hình nghiên cứu của Deane (2005) và Kövecses (2017), trong đó nhấn mạnh rằng khi phân tích hình ảnh không gian của giới từ, ta cần có sự kết hợp đa chiều. Xét về nghĩa phi không gian, thì mỗi nghĩa sẽ kích hoạt một ẩn dụ mang tính tầng lớp từ khung của nó trong một ngôn cảnh với mục đích giao tiếp cụ thể đến miền chứa khung và cuối cùng là hình ảnh - lược đồ, cái mà tương trợ cho khung tri nhận trong hoạt động chủ thức của con người.

Từ khóa: ẩn dụ, over, chuyển nghĩa, cơ chế 